\title{
CHALLENGES FOR REGIONAL GOVERNANCE IN TURKEY: THE ROLE OF DEVELOPMENT AGENCIES (1)
}

\section{Ebru ERTUGAL*}

Received: 24.10.2016; Final Text: 16.05.2017

Keywords: Policy instrument; regional development; governance; development agencies; Turkey.

1. This work was supported by the Scientific and Technological Research Council of Turkey (TÜBITTAK) under Grant No: 109K443 (entitled 'The European Union and the Transformation of Policy and Governance: Case Study of Turkey in Three Policy Areas').

\footnotetext{
* Department of Political Science and International Relations, Başkent University, Ankara, TURKEY.
}

\section{INTRODUCTION}

Regional development agencies (DAs) have been operational in most regions of Europe since the 1990s. Charged mainly with the task of stimulating bottom-up development based on the mobilization of local and regional resources, DAs have to work in partnership with other local and regional organizations (Danson and Lloyd, 2012; Halkier, 2012a). DAs differ widely across jurisdictions in terms of their origins, size, tasks, and degree of autonomy. While in some countries DAs are the products of local bottom-up initiatives without national coordination, in other countries they are formed by national governments. Still in some other (especially federal) countries DAs are initiated by city or regional government action in partnership with private sector actors. DAs also differ significantly with respect to the wider institutional settings in which they operate. This suggests that DAs have different potential, and scope, for entering into relationships operating between and across different tiers of government (local, regional, national, supranational) in multi-level settings and they have differing capacities to take part in multi-local dynamics.

As against the background of mushrooming regional development agencies in most European countries in the past four decades, DAs did not come into existence in Turkey until the mid-2000s, with the exception of a few local bottom-up initiatives. The critical turning point came with Turkey's admission as a candidate country to the European Union (EU) in December 1999. The EU requirement to set up DAs was first mentioned in the Accession Partnership Document in 2003 as part of the efforts to align Turkey's regional policy with that of the EU.

Throughout the 1990s and until the mid-2000s, EU conditionality and pre-accession financial assistance programs promoted the removal of the "exclusive right" of the central state to define the means and goals of regional development not through formal constitutional changes but through "the setting of the rules and principles of the disbursement" of 
the pre-accession funds (Bruszt, 2008, 614). These principles included the formation of DAs in countries where regionalized institutions did not exist, hence making DAs the goal of policy for encouraging the decentralization of regional development governance (Hughes et al., 2004; Bache, 2010). This approach has been part and parcel of the EU's regional policy since the first major reform of the Structural Funds, the main delivery mechanism, in 1988 (CEC, 1988). The 1988 reform introduced the principles of partnership and subsidiarity, which envisage shared decision-making across territorial levels. This potentially provides for greatly enhanced regional involvement in policy-making, and thus introduces a bottom-up approach to regional policy design, implementation and monitoring. The main policy idea behind these principles is to promote regional development through bottom-up, local initiatives, networks and soft factors such as research and development (Keating, 2008). The EU's promotion of the regional level in candidate countries took a sharp turn in the mid-2000s and instead put an emphasis on centralized planning and delivery of regional policy in candidate countries mainly as a response to the experience of irregularities in the management of pre-accession funds (Hughes et al., 2004; Bache, 2010). As a result, in contrast to the former candidate countries of Central and Eastern Europe, DAs in Turkey do not play a role in the administration of EU financial assistance.

For Turkish officials, the DAs strictly represent policy instruments rather than a policy goal of decentralization. In a separate research carried out by the author in Summer 2015, all 15 mid and high-level bureaucrats interviewed at the General Directorate for Regional Development and Structural Adjustment in the Ministry of Development concurred in the following statement: "Regional Development Agencies have never been an aim of regional policy in Turkey. They [DAs] solely represent instruments for policy implementation" (Ertugal, forthcoming). The assumption behind the conception of DAs as policy instruments by national policy practitioners is that DAs are apolitical, neutral and technical devices for achieving optimum development outcomes. This article, in conformity with the prevailing notion of DAs as instruments among national policy practitioners, examines the functioning of the DAs in Turkey from a policy instruments approach. In doing so, however, this article challenges the notion that policy instruments can be apolitical or neutral. This is where this article departs from the assumptions held by national policy practitioners. Instead, as the next section will elaborate, it is argued that policy instruments do have significant political and power implications in contrast to the liberal and modern disguise under which they are conceived or presented (2). Therefore, the policy instruments approach adopted in this article seeks to uncover both the intended and unintended effects as well as the political consequences of DAs in their functioning in order to answer whether DAs could become focal points for empowerment of sub-national actors and mobilization of endogenous growth capacities. It aims to shed light on the potential of DAs to institutionalize regions as legitimate political forms if the former are to be effective agents of economic development. The article proceeds by elaborating the policy instruments approach and how it is used to capture important dimensions of DA activity. The next section presents the research design and sources of data. This is followed by a presentation of empirical findings. The final section on Conclusions summarizes the main findings.
2. An increasing amount of research demotrates the political effects of various policy instruments such as the Regulatory Impact Assessment (Dunlop et al., 2012) or the Impact Assessment (Radaelli and Meuwese, 2010). Perhaps the best example for the purposes of this article is the work by Bache (2010) who shows how the partnership instrument in EU regional policy, although presented as a technical device, has been a highly political instrument with different purposes and effects in different contexts. 


\section{THE POLICY INSTRUMENTS APPROACH}

The policy instruments approach was recently advanced by Lascoumes and Le Gales (2007) and Kassim and Le Gales (2010) building on previous work by Salamon (2002) and Hood (1986). This approach challenges the functionalist view that instruments are merely technical and neutral devices for realizing policy aims in the most effective way. In fact, as Majone (1989) argues, policy instruments are never neutral. Instead, policy instruments approach argues that policy instruments produce their own effects independent of the aims attributed to them (Lascoumes and Le Gales, 2007; Kassim and Le Gales, 2010):

"A public policy instrument constitutes a device that is both technical and social, that organizes specific social relations between the state and those it is addressed to, according to the representations and meanings it carries (Lascoumes and Le Gales, 2007, 4)."

This definition has two implications. First, as instruments of regional policy, the DAs should be studied through focusing on their instrumentation, which requires an understanding of how they are operationalized or the kind of effects they produce (Lascoumes and Le Gales, 2007, 4). These effects include both a technical component involving their operational quality, techniques and procedures, and a social component, which directs attention to their meaning for power relationships and how they are used/interpreted by different actors. The social component captures the political dimension of instruments. In this process of both technical and social instrumentation, the DAs acquire meaning that goes well beyond their instrumental value. Second, analyzing the effects of instruments necessitates their conceptualization as institutions (Lascoumes and Le Gales, 2007; Kassim and Le Gales, 2010). The DAs, as institutions, inevitably shape actor behavior, privilege certain interests over others and favor certain policy solutions over others. The policy instruments approach, therefore, recognizes the gap between rules embedded in the technical component of instruments and their implementation by actors (Streeck and Thelen, 2005, 13). Since actors do not necessarily blindly follow the rules there is almost always an unavoidable element of "openness in the interpretation and implementation" of rules (Mahoney and Thelen, 2010,10). This is why it is important to uncover both the intended and unintended consequences of instruments, which may otherwise go unnoticed due to their legitimization based on their modernist and liberal image.

There is no one single framework with which to approach the DAs as instruments. As mentioned in the introduction, the DAs have acquired increasingly complex structures and are highly differentiated across jurisdictions. Hence, there are a myriad of ways in which the DAs can be studied depending on the theoretical framework adopted and the contextspecific features. For the purposes of this article the four key dimensions identified below represent the most relevant features to be investigated for understanding the political, power and governance effects of DAs in order to assess their potential to become focal points for empowerment of sub-national actors, mobilization of endogenous growth capacities and to institutionalize regions as legitimate political forms. While existing comparative and case studies of the DAs do not exhibit a common, unified framework for analysis, many of them utilize either one or more of the dimensions identified in this article (Syrett and Silva, 2001; Shaw and 
3. The draft version of the law establishing DAs in Turkey contained a 40-page long justification when it was first submitted to the Turkish parliament. In the text provided for justification, the mandate of DAs is defined to include the promotion of innovation and competitiveness in the regions (Draft Law, 2005).
Lloyd, 2000; Ferry, 2007; Pike et al., 2012; Johansson and Rylander, 2012; Bramanti and Rosso, 2012).

The analytical focus, as befits a policy instruments approach, is both on the technical and social instrumentation of DAs and the (un)intended consequences that the process of instrumentation produces. Based on recent studies of regional DAs operating in various European countries, four key dimensions of the DA activity have been identified for analysis. First, existing research increasingly points to the critical role played by the regional level in innovation and growth (Crevoisier and Jeannerat, 2009; Visser and Atzema, 2008). Supporting and stimulating knowledge dynamics in regions and building on the strengths of regions constitute the main pillars of EU regional policy (Böhme and Waterhout, 2008). In this context, the DAs have a special mandate, or at least are expected to flexibly manage and improve knowledge dynamics among multiple actors in the regions in order to foster competitiveness. Given the confirmed link between innovation and governance (Fagerberg and Srholec, 2008), it is impossible to imagine a successful region without a DA with a substantial level of technical and operational capacity (Roncevic, 2012). This renders the analysis of their techniques and procedures involving operational qualities, including staff, resources and flexibility essential for evaluating their capacity to promote competitiveness. It is the DAs with qualified and adequate human resources, knowledge assets, and with intra-regional networking skills that are likely to gain the kind of political legitimacy that would allow them to be an engine of development (Bellini et al., 2012b). Given that competitiveness is the mandate of Turkish DAs too, more specific questions in this dimension relate to key positions in the DAs, how they are selected and resources of the DAs (3).

The remaining three key dimensions identified for this article relate to the social component of the DA instrumentation. Given that the DAs are not supposed to be stand-alone units, but rather part of a continuous process of interaction, negotiation, guidance, and/or persuasion with other public and private actors, the social component directs attention to these complex relationships. One of the manifestations of these complex relationships is the embedding of the DAs among public and private economic actors of the region, whereby the latter become partners (Jones, 2003). Existing research shows that such partnershipping runs the risk of the DAs being captured by vested interests, potentially causing the DAs to lose their ability to take on a long-term objective view of development initiatives (Bellini et al., 2012a, 3; Larsen, 2012). This risk is especially greatest in peripheral and lagging regions, where the type of change that a region needs may not take place for being contrary to the self-interest of the local elite (Barca, 2009a, 21; Acemoğlu and Johnson, 2006, 328). It is thus imperative to investigate the involved partners in the DAs and their interrelationship in order to understand whether the DAs are captured in regressive coalitions of established interests and power relations. To the extent that short-term inward looking concerns dominate the DAs' agenda, the extent to which the DAs can make a difference is debatable.

Another manifestation of the DAs' complex relationships is in the architecture of multi-level governance. Much has been written about the shift towards multi-level governance and network relations within which the DAs constitute an integral feature (Cooke and Morgan, 1993; Marks, 1993; Halkier and Danson, 1997; Bache and Flinders, 2005; Halkier, 2006). Given that the DAs cannot be expected to be the sole providers of answers 
to development challenges in the regions (Bellini et al., 2012b), the patterns of their coordination with local actors and with other tiers of government need to be investigated. If multi-level governance is operating in inflexible and segmented ways, the extent to which the DAs can fulfill their mandates is highly limited. Whereas the horizontal dimension of multi-level governance concerns the degree of participation of local stakeholders in the activities of the DAs, the vertical dimension concerns the nature of relations with the central administration. It is important to identify who has the "formal monopoly of taking a binding decision" for issues of regional development and whether central intervention is for the purpose of removing development traps, leaving discretionary powers with regard to strategic initiatives and implementation to the DAs (Bruszt, 2008, 611; Barca, 2009b).

Still another manifestation of complex relationships is the DAs' ability to contribute to a great degree of integration between different policy areas (Johansson and Rylander, 2012). Halkier and Danson (1997) call this the integrated implementation capacity. The ability of the DAs to integrate between different policy areas is crucial if parallel policies instituted by other tiers of government that address similar issues are not to preclude efforts by the DAs (Halkier, 2012b). This ability partly depends on the number of policy areas in which the DAs are engaged and the diversity of policy resources (hard and soft) at their disposal (Halkier and Danson, 1997, 246-50). Integrated implementation more crucially depends on the administrative capacities for co-ordination between both line ministries such as for health, education, transport, industry, agriculture and environment and lower levels of local governance such as municipalities.

These four dimensions together capture the "multiscalar" quality of the DA activity (Gertler, 1997, 48). Despite the fact that the contemporary DAs are characterized by highly differentiated functions, structures, powers and strategies operating within diverse political, economic and social environments (Halkier, 2012a), the major challenge commonly faced concerns their capacity to carve out a role as "strategic power-brokers" between the central administration and those bodies already present in the region (Pearce and Ayres, 2009, 537; Webb and Collis, 2000; Ferry, 2007). This was also recognized in one of the rare and earlier studies on the DAs in Turkey, which argued that enjoying institutional legitimacy would be the main challenge (Lagendijk et al., 2009; Kayasü and Eldeniz, 2013). With regard to implementation, the DAs have to influence the investment decisions of public bodies operating in the region and putting mechanisms in place to draw lessons from project and program evaluations and improvement of the regional database (Tewdwr-Jones and Phelps, 2000).

\section{THE RESEARCH DESIGN AND METHODOLOGY}

This article combines documentary review with semi-structured interviews in six different regions of Turkey conducted between 2011 and 2014. Documentary review includes a compilation of relevant statutory legislation, annual activity reports conducted by the Ministry of Development, external evaluation reports, parliamentary minutes, and regional plans, working programs and activity reports of DAs published on their websites covering the period 2010-2016.

In total 37 semi-structured interviews were conducted in six regions (For a full list see Appendix 1). In selecting the interviewees, attention was paid to 
select respondents in different settings with varying degrees of relationship to the DAs. Twenty-four of the interviewees represent top and mid-level management in local organizations that are members of either the decisionmaking or the consultative bodies of the DAs. Nine of the 24 interviewees do not participate in the activities of the DAs on an individual basis (interviews 8, 9, 14, 16, 32, 33, 34, 36, 37 in Appendix 1). Attention was also paid to have a balanced representation of the public and private sectors and civil society in each region. The remaining 13 interviewees represent the staff working full-time for the DAs. The number of interviewees in each region was largely determined by the principle of saturation, whereby a threshold was reached after which findings kept repeating themselves.

Interviews were conducted in six Nomenclature of Territorial Units for Statistics (NUTS) II regions which comprise: 1) İzmir, 2) İstanbul, 3) Çukurova (Adana-Mersin), 4) Mardin-Batman-Siirt-Şırnak, 5) ŞanlıurfaDiyarbakır, and 6) Kastamonu-Çankırı-Sinop. Of the selected six regions, the Gross Domestic Product (GDP) per capita of the first three regions is above $75 \%$ of Turkey's average, whereas the GDP per capita of the three latter regions is less than $75 \%$ of Turkey's average. The income difference between the richest region (İstanbul) and the poorest region (MardinBatman-Siirt-Şırnak) is almost fourfold. The reason for selection of regions based on GDP per capita levels is to ensure representativeness through capturing potential diversity so that findings could be generalized to all regions in Turkey.

The purpose of the interviews was to elicit data on four dimensions of the DA activity outlined in the previous section. Information gathered through interviews was converted into text by means of transcription. Interpretation of the content of the text was based on two types of categorization. First, the information source was identified in terms of the site of the interviewee (characteristics of the relationship to the DA). Second, patterns of issues and relationships were identified within and across text. In doing so, both similarities and differences across the text and the underlying reasons for these patterns (such as the sites of the interviewees) were identified. Observed patterns in interview data were then compared and contrasted to patterns observed in documentary review. Thus, the analysis in this article is based on triangulation of both methods (interviews and documentary review) and different data sources (interviewees based in different regions and in different settings) (Denzin, 1989). It should be emphasized that the interview data, analyzed as such, displays strong convergence around certain themes regardless of the sites of the interviewees (whether representing the public sector, the private sector or the civil society). In reporting interview data, recurring themes around which there is strong convergence are emphasized. Also, information is provided concerning the number of respondents who emphasize recurring themes in order to convey a sense of the strength of the patterns observed (rather than a quantitative distribution of attitudes). Interview quotes are used merely to illustrate these patterns. Where direct interview quotes are used, the interviewee number is mentioned in brackets, which can then be traced to the list provided in Appendix 1 to see whether that particular interviewee represents the public or the private sector or the civil society.

The purpose of this study is to shed light on the dominant characteristics of regional governance challenges centered on the DAs. In doing so, the focus of the article is mainly on revealing common patterns across regions, even though their intensity and the exact ways in which they play out differ 
from region to region and over time. The concluding section of the article includes a brief discussion of regional differences.

\section{DAs AS POLICY INSTRUMENTS: BACKGROUND AND EMPIRICAL FINDINGS}

\section{Background}

Statistical regions at NUTS II level in Turkey were formed in 2002 by bringing together NUTS III regions, provinces, which constitute the main territorial administrative unit. Of the 26 NUTS II regions in total, only three are at the same time NUTS III, provinces of Ankara, İstanbul and İzmir. The rest of the NUTS II level regions consist of two or more provinces. It was decided to set up the DAs for each NUTS II level region by law adopted by parliament in 2006 (Official Journal, 2006a). Adoption of the law was followed by a period of legal challenges which were finally resolved in 2007 after which the DAs were gradually established. Turkish DAs, therefore, have a very recent history with only two pilot DAs (İzmir and Çukurova) having existed since 2006.

According to law, the composition of the DAs for each region is the same except for some minor differences in regions that consist of one province only, Ankara, İstanbul and İzmir. All the DAs have three main units: decision-making body, consultative body and executive body. The decision-making body, the Board of Directors, is composed of the following local actors: governors of the provinces that make up the region, heads of provincial assemblies, mayors of municipalities of the provincial centers, presidents of provincial chambers of commerce and/or industry. In regions made up of one province only, the decision-making body includes three additional members representing the private sector and/or civil society, who are elected by the consultative body. The law stipulates that the consultative bodies, Development Councils, should comprise 100 members representing the public and private sectors and civil society. The executive bodies in the form of General Secretariats constitute the full-time staff of the DAs conducting day-to-day operations. A General Secretary heads General Secretariats. Both the General Secretaries and the staff under them work on a contractual basis.

The Ministry of Development coordinates the activities of the DAs. Decisions taken by the Board of Directors concerning regional plans, working programs and the budget are subject to the approval of this Ministry while regional plans also have to get the approval of the Regional Development High Board composed of ministers of line ministries. Most of the financial resources of the DAs come from the general budget. Responsibilities of the DAs include mobilization of local resources through forming regional partnerships, preparation and implementation of regional plans, promotion of regional development and regional competitiveness, and reduction of intra-regional disparities.

Similar to those in European countries, the DAs in Turkey rely primarily on soft policy resources in the form of grants for (co)funded projects, (in)direct forms of financial support as well as informational and organizational support to small and medium sized enterprises. The only traditional policy instrument at their disposal is inward investment offices to help potential investors with paperwork. Again similar to the DAs in Europe, the main targets of policy are public institutions and private firms (such as governorates, municipalities, chambers) operating in the 
region (Dahlström et al., 2012, 15-6). With regard to their strategies, the objectives of the DAs in Turkey as expressed in the regional plans are almost in unison with those in Europe reflecting the competitiveness oriented EU-Lisbon Strategy (Dahlström et al., 2012, 33). In the first round of regional plans formulated for the period 2010/2011-2013, the efficiency objective (regional competitiveness) clearly dominated as opposed to the equity objective (equality-oriented goals). The latter entered into plans in only 13 of the 26 regions (Working Group, 2012). In the second round of regional plans for 2013-2023, both efficiency and equity objectives are given almost equal weight in a majority of the regions. However, the financial, informational and organizational support programs of all the DAs aimed at implementation clearly favor the efficiency objective.

There are several problems with regard to the position of the DAs within Turkey's system of public administration. Prior to the 2002 decision of the Council of Ministers, no statistical or planning regions existed at the NUTS II or any other sub-national level. The DAs, established by law, correspond to the NUTS II level regions. While the DAs are conceived as semidepartmental (through the Board of Directors) legal entities, they do not have a constitutional status. Moreover, the DAs do not fit into any of the administrative concepts defined in Turkey's Constitution. Even the term agency is an alien concept. The law establishing the DAs does not define the latter as "regional administrations". Moreover, the DAs do not form a part of the central administration or the field organization of the central administration or the local administration. Hence, the status of the DAs within the hierarchical administrative structure and vis-à-vis the centerlocal relations remains ambiguous. Lack of clarity in the DAs' relationship to other public institutions potentially creates problems of overlapping competencies and authority especially where they carry out similar aims.

\section{Empirical Findings}

This section presents the findings of this study for each of the four dimensions of the DA activity identified in line with a policy instruments approach.

Operational Qualities: Staff, Resources, Flexibility and Innovation

Research on the DAs in European countries has unequivocally shown that people and money are the key assets that make a difference to their performance (Bramanti and Rosso, 2012, 270). The technical skills of staff are the outcomes of long years of training, project management and trial and error procedures (Bramanti and Rosso, 2012, 275). Equally, most of the DAs in Europe are sponsored by several tiers of government (national, regional and local), which enables the former to operate as semiautonomous entities strengthening the arm's length principle (Halkier, 2012b, 38).

In the Turkish DAs a distinction is made between the General Secretary and the staff (Official Journal, 2006b). The recruitment of the General Secretary is based first on a nomination by the Board of Directors and second on the approval of the Ministry of Development. The Board of Directors can unilaterally terminate the employment contracts of General Secretaries. In the recruitment of expert and supporting staff, candidates who are new graduates are required to have received a certain level in nation-wide professional and language examinations held for entering the civil service (Official Journal, 2006b). Having passed those thresholds, candidates are then invited to job interviews. Official reports confirm that 
these procedures are being adhered to (Kalkınma Bakanlığı; 2012; 2013). All 37 interviews further confirm that high-quality staff was recruited for the DAs, even in the lagging regions.

Opportunities are severely limited with regard to promotion. All of the staff interviewed stress that there is not a promising career path. The best that the expert staff can do is to be promoted as the head of unit. There are five units on average in each DA where between 30 and 40 personnel work as experts (Kalkınma Bakanlığ1, 2013). There is the possibility that the head of a unit could be appointed as the General Secretary. However, according to law the latter could equally be appointed externally. Another important factor for retaining staff is the level of wages. The High Planning Board, composed of ministers, set the level of the DA staff wages higher than the salaries of bureaucrats in the capital in 2009 when the first round of recruitment had started (Sayıştay Başkanlığı, 2014). In the words of an interviewee, it was "as a consequence of relatively high wages that highquality staff could be attracted to the least developed regions" (interview 13). Since then, however, wages have deteriorated due to inflation and "lack of any decision taken by the High Planning Board" to enable an upward adjustment in wages (Devlet Denetleme Kurulu, 2014, 788-89) so that "it has become more attractive to work in the civil service in Ankara as the wages are about the same" (interview 24). As a result, the DA staff is losing motivation and looking for jobs elsewhere (Devlet Denetleme Kurulu, 2014, 788). According an interviewee's observation there is "30 percent staff loss" in the DAs of the lagging regions (interview 23).

There is a high degree of openness to learning new technologies and methods of analysis in regional planning among the DA staff as a function of their quality and young age. However, they often come from diverse backgrounds and need at least a certain level of orientation in development. Beyond that, interviewees stress training needs in areas such as cluster analysis, input-output analysis and projection as the DA staff in general have weak competency in regional planning methods and analysis (Devlet Denetleme Kurulu, 2014, 791). In order to meet these needs the Ministry of Development provides a minimum of ten days of training every year (Kalkınma Bakanlığı; 2012; 2013), which according to most interviewees is nowhere near sufficient. Inadequacies of both formal training and on the job experience due to high levels of staff turnover undermine flexibility and innovation in operational functions. This weakness is further aggravated by the lack of reliable data at local and regional scales, which leads to not only the production of sub-quality regional plans (especially in the first round) (Devlet Denetleme Kurulu, 2014, 778-80), containing hardly any spatial analysis and sophisticated outcome indicators, but also to the incomparability of analyses across regions.

Fiscally, not only the size of the DA budgets is meager but they are also overwhelmingly dependent on the central government. Annually $0.05 \%$ of the general budget is allocated for the DAs. This represents around $85 \%$ of the DAs' financial resources. The rest is provided by contributions from municipalities, provincial assemblies and chambers of commerce and/ or industry. The annual budget of a DA is roughly around $€ 30$ million. Almost all of the interviewees are in agreement that the minimal size of the DA budgets reduces their relevance in regional development governance. Moreover, excessive dependence on the central government is a crippling factor for the arm's length principle threatening to render the DAs as mere extensions of the central administration. 


\section{Power Relationships}

Responses to 30 out of 37 interviews indicate that there are significant efforts to divert financial resources of the DAs for particularistic interests as opposed to the general interest. In the words of an interviewee, "the members of the Board of Directors are in competition to influence the distribution of the financial resources" (interview 19). The Board of Directors "applies pressure on the General Secretary to make sure that project applications on behalf of their institutions or from their clients qualify for funding" (interview 29). Since institutional members of the Board make compulsory contributions to the DA budget, "each wants to get back as much as possible through winning grants" (interview 21). At a minimum, Board members seek to influence the evaluation of project proposals, which should be an independent process (interview 21). Additionally, there is rivalry between provinces that make up the region. Most provincial governors "engage in cheap thinking calculating the number of projects that receive grants in their province as opposed to the number of projects in other provinces" (interview 14). Hence, there is a widespread perception that the DA financial support tends to benefit particularistic interests rather than the general interest. The evaluation report stresses that the distribution of financial resources through grants has come to dominate DAs' operations at the expense of the provision of informational and organizational resources (Devlet Denetleme Kurulu, 2014, 777). Moreover, despite legislation to the contrary, the financial resources of the DAs are used to support the routine activities or to lower operational costs of those local organizations that are Board members (Devlet Denetleme Kurulu, 2014, 785) (4).

The calls for proposals as part of the grant scheme that the DAs administer constitute another potential channel through which the members of the Board of Directors try to influence the diversion of financial resources. Whereas the purpose of the calls for proposals should be to implement a specific part of the regional plan, the majority of the interviewees among the DA staff claim:

"There is no relationship between the calls for proposals and the regional plan. Those in the Board of Directors do not even read the regional plan. For example, the Chamber of Commerce and Industry wants to support a specific sector. So we announce a call for proposals for that sector. Every year we announce calls for different sectors. One year we support the tourism sector, the next year we support leather manufacturing. Despite limited resources there is no long-term thinking. If we support one sector this year why should we withdraw from that sector the next year?" (interview 30) (5).

A review of regional plans and calls for proposals for 26 DAs shows that priorities outlined in most of the calls tend to be largely repetitions of the general aims of the regional plans due to weaknesses in the DA staff competencies and lack of reliable regional databases. As most of the interviewees concur, this leaves considerable leeway in the distribution of financial resources to a potentially wide range of priorities at the implementation stage, which cannot be monitored and evaluated according to pre-determined measurable indicators, increasing the possibilities for political influence.

Local power relationships appear to be more debilitating for the lagging regions. In the regional plan for Mardin-Batman-Şırnak-Siirt region for example, Measure 2.2.1. explicitly states that the determination of the
4. This issue was the subject of a motion the main opposition party to investigate the distribution of DAs' financial resources, which are claimed to be used for purposes contrary to law to support the purchase cery and equipment of certain activities of local authorities (TBMM, 2012). The proposed motion was however dect alid due to the failure to conclusion by the end of the legislative year.

5. The weakness of the relationship between regional plans and calls for proposals is also highlighted in Devlet Denetleme Kurulu $(2014,777-80)$ 
location of new industrial sites "should not be according to political and local pressures", but on the basis of analyses informed by scientific data (Dicle Development Agency, 2013, 326). Similarly, Measure 1.7.4. of the same plan states that in supporting new entrepreneurs action should be taken "to avoid local pressures" (Dicle Development Agency, 2013, 290). According to the plan entrepreneurship and production in the region are monopolized by a few families and consequently potential young entrepreneurs outside these families are discouraged from commercializing new ideas (Dicle Development Agency, 2013, 290).

Interview responses additionally indicate the presence of serious problems in the procedures for independent evaluation of project proposals. There is widespread perception of "unfair distribution of financial resources" (Devlet Denetleme Kurulu, 2014, 782-83). All of the interviews with the DA staff further concur that there is a general perception among local stakeholders that the DAs can be used simply to make money. These empirical findings suggest that there is a real danger that the distribution of financial resources may be dominated by the short-term inward looking concerns of the local political and business elites.

\section{Multi-level Governance}

With regard to the horizontal dimension of multi-level governance, 35 out of 37 interviewees claim that the process of formulating both the first and the second rounds of regional plans were participatory to a great extent. Activity reports of the DAs further show that in every region the process of formulating regional plans involved extensive meetings, workshops and surveys with thousands of local people. Interviews indicate, however that these participatory processes were one-off, limited to the plan preparation stage and as such did not continue beyond that stage. With regard to the Development Councils, which were designed to engage societal actors in the day-to-day activities of the DAs and thus to ensure ongoing, regular participation, most of the interviewees are unison in agreement that they - the Development Councils - "are completely ineffective" (interview 24). The membership of the Development Councils for each DA is determined by the Council of Ministers at the central level, who updates the list of members at certain intervals. According to this list, the public sector dominates membership at the expense of civil society (Official Journal, 2013). Moreover, according to law the decisions of the Development Councils are not binding for the Board of Directors (Official Journal, 2006a). The issue of participation gets even more complicated in regions in the Southeast where identity politics dominates and where mayors and provincial councils represent pro-Kurdish political parties, who are outright opposed to the DAs viewing them "as the sub-national face of the central state" (interview 10). In these regions "some of the members do not even attend the meetings" (interview 16) and there is "a general climate of impossibility of cooperation among members of the Council created by ideological polarization" (interview 27). The evaluation report observes that participation in the meetings of the Development Councils across all regions has declined over the years while no meetings at all take place in several regions (Devlet Denetleme Kurulu, 2014, 779).

The failure of the DAs to engage with local stakeholders on a regular basis is compounded by the weakness of the bottom-up demand for development policies according to interviewees. While labor and civil society in Turkey in general are weak, they also lack regional territorial 
6. It was explained in section 2 under "The Policy Instruments Approach" that the purpose of this article is to uncover both the intended and unintended consequences of DAs. It follows that the gap between rules embedded in the technical component of instruments and their implementation by actors is a subject of empirical investigation. Hence, it was a possibility that the Ministry of Development could have in practice only overseen development in general terms and could have left considerable discretionary powers with regard to strategic initiatives and implementation to the DAs. However, the fact that most of the interviewees, irrespective of whether they represent the public or private sectors or the civil society, concur that this has not been the case is a significant finding. organization and cannot politicize and translate regional problems of economic development into effective political demands.

With regard to the vertical dimension of multi-level governance, the interviews suggest that the interventions of the Ministry of Development both exceed its coordinative role provided in law and do not intend to remove development traps involved in local power relationships. Thirtytwo out of 37 interviewees complain that "centralization is still the norm" (interview 20) (6). One interviewee claims:
"An ordinary civil servant in Ankara may object to a decision taken through participatory processes by the DA. For example, in the regional plan most of the stakeholders in the region take part in determining which sectors to be supported. However, a civil servant in the Ministry of Development may disagree and tell us to support another sector" (interview 15).

The excessive interventions of the Ministry of Development in the decisions of the Executive Boards not only undermine the accountability of the latter, but also render the DAs "inflexible, slow-moving and non-participatory" structures (Devlet Denetleme Kurulu, 2014, 779). Furthermore, there is widespread agreement among interviewees concerning the absence of a clear strategic orientation on the part of the Ministry of Development (see also İzmir Development Agency, 2016, 108-9). In the words of an interviewee:

"The bureaucrats at the Ministry of Development do not know what they want out of the DAs and they are confused about how they should guide them" (interview 32).

This is partly related with the fact that within the Ministry those responsible for the co-ordination of the DAs are (assistant) experts dispersed among various units where DA-related work is of secondary importance (Devlet Denetleme Kurulu, 2014, 795).

Research on other forms of central government intervention also shows that the relevance of multi-level governance is undermined especially in certain metropolitan regions. As argued by Eraydın and Taşan-Kok (2014), even though planning rights for metropolitan areas were decentralized to municipalities in the early 2000s, in the following years these rights were rapidly transferred back to several central government bodies including various line ministries (such as for industry, tourism and environment) as well as the Housing Development Administration (TOKI). Research on İstanbul, for example, shows how the top-down decisions of the urban coalition consisting of the central government, local authorities and TOKI driven by urban land rents and real-estate development define İstanbul's development (Türkün, 2011; Organization for Economic Cooperation and Development, 2008). This is in sharp contrast to the vision formulated for İstanbul in the regional plan for 2014-2023, which centers around an innovative economy based on high value added manufacturing, social inclusion and environmental sustainability (İstanbul Development Agency, 2014).

Multi-level governance, in both horizontal and vertical versions, as practiced in Turkey is therefore at the hierarchical end of a spectrum where the other opposite end is of a networked type.

\section{Co-ordination}

Given that the number of policy areas and the diversity of policy resources at the disposal of the DAs are quite limited, implementation of regional 
plans is highly dependent on the DAs' capacity for co-ordination of public investments in their region. The non-binding nature of regional plans over decisions concerning national investments and local plans prepared by municipalities is frequently described as the "biggest handicap" faced by the DAs among interviewees (interview 25) (see also İzmir Development Agency, 2016, 108-9). In fact, 29 interviewees out of 37 think that regional plans should be binding and should have own budget for implementation.

A number of steps have been taken to facilitate co-ordination at the central level, as a majority of the interviewees point out. One is the formulation of a National Strategy for Regional Development (BGUS) to provide a framework and orientation not only for regional plans but also for line ministries (Kalkınma Bakanlığı, 2014). Another is the formation of a Regional Development High Board composed of ministers (such as for industry, technology, labor and social security, agriculture, transport, tourism, environment and urbanization, and forestry) and a Regional Development Committee composed of undersecretaries. The expectation out of these initiatives is for line ministries to "acquire a sense of ownership" (interview 12) over the regional plans and hence make their investment decisions accordingly.

There are a number of reasons for claiming that this expectation is naïve at best and these reasons do not even include the fact that some key ministries for regional development (such as for education and health) are absent in the Regional Development High Board. Research on horizontal co-ordination in the European context has shown that macro-level processes, such as the acceptance of BGUS as a general policy principle, do not necessarily influence the micro-level of everyday policymaking (Schout and Jordan, 2007). There are strong path-dependencies in the functional specialization of the public sector in Turkey and policy-makers working on individual items of policy can too easily ignore consideration of regional consequences. The following remark by the representatives of public institutions (provincial directorates of line ministries) interviewed illustrates the challenge: "Our budget is 16 times bigger in comparison to the DA budget. What can they achieve that we cannot?" (Interviews 17 and 35). While this remark obviously shows that the tiny size of the DA budgets decreases the latter's relevance for other actors in the region, it also alludes to the fact that public sector rationality is geared towards solving core tasks rather than collaborating for a greater public good. Hence, effective co-ordination requires nothing less than administrative implementing mechanisms in day-to-day policy processes for identifying priorities, carrying out impact assessments, and sustaining the necessary political pressure (Schout and Jordan, 2007, 842).

\section{CONCLUSION}

This article evaluates the challenges for regional development governance in Turkey by focusing on the role of Regional Development Agencies. In doing so, the article shows that as seemingly neutral and technical policy instruments, the DAs are in fact highly political and politicized and have important political consequences. Empirical findings suggest that the effects of technical instrumentation or operationalization of the DAs are such that their human resources and knowledge assets are not adequate. Even though highly-qualified personnel were recruited to begin with, the loss of staff over time and high turnover rates, coupled with insufficient training provided for requisite skills, make it almost impossible to 
accumulate long years of experience and learning through trial and error. Hence, empirical evidence suggests that the DA staff, by and large, do not possess the necessary technical and political skills and experience to manage multiple actor dynamics in the regions and to form intra-regional networks. Potentially, the General Secretary could play such a pivotal role. However, empirical evidence on the effects of social instrumentation of the DAs shows that General Secretaries are overwhelmed by pressure from local actors represented in the Board of Directors. The kind of pressure exerted by local actors represented in the Board of Directors, as empirical evidence shows, is for engagement about a certain exchange (receiving as much of the financial resources distributed by DAs as possible) rather than for a long-term engagement to realize a certain imagined future for the region. The latter requires that the DAs generate partnerships with the potential to produce new possibilities for the partners and their interrelationships and in so doing, produce new collaborations, new ideas and visions of development. In Turkey's case, it can be clearly deduced from empirical findings that local actors perceive the DAs as devices for accomplishing their own objectives rather than as partnerships for producing new possibilities of development.

On the basis of empirical evidence concerning other dimensions of the social instrumentation of the DAs, it can be claimed that there is no collaboration among actors within all stages of the policy cycle, which, if existed, would have contributed to better strategy formulation and implementation. The local actors, including not only those represented in the Board of Directors but also more broadly in the Development Councils and beyond, participate meaningfully only in the plan preparation stage. However, plans are multiannual and hence plan preparation stage takes place only once every few years. At the decisionmaking and implementation stages, DAs operate according to the logic of top-down framing, whereby the Boards of Directors take decisions without involvement of Development Councils. In turn, the Ministry of Development unilaterally interferes in decisions taken by the Boards without leaving any discretionary power to the latter with respect to strategic initiatives and implementation. The local actors not represented in the Boards of Directors participate neither in decision-making nor implementation stages. Thus, evidence of multi-level governance is weak. To the extent that multi-level governance exists, it operates in highly inflexible and segmented ways. This hinders the DAs from mobilizing endogenous growth capacities. Empirical evidence concerning the social instrumentation of DAs further shows that top-down framing also produces effects that render the DAs without capacity for integrated implementation as the plans they formulate are neither binding nor have their own budget. The solutions sought at the central level through forging institutional coordination mechanisms have the effect of removing the DAs further from the center stage of policy integration, greatly hindering the latter from becoming engines of development in their regions.

These empirical findings suggest that, on the whole, the DAs lack the capacity to act as focal points for empowerment of sub-national actors and to foster cross-sectoral collaboration between public and private sectors and civil society. Hence, it can be argued that the DAs neither have the potential to be engines of development nor the potential to institutionalize regions as legitimate political forms. As such the DAs are largely failing to manage multiscalar relations of governance for the purpose of promoting regional development. The findings show that the crucial added value of the 
Turkish DAs is to act as the interpreter of territory needs and expectations through formulating regional plans, which often involve more diverse developmental perspectives than provided for by the National Strategy for Regional Development. This benefit is, however, lost due to lack of power, lack of resources and weak administrative capacity of the central administration to remove local development traps. In particular, the onesize-fits-all approach for regions that are socio-economically, politically and ethnically diverse is proving to be highly inadequate. In sum, the DAs in Turkey represent a form of institutional "layering" (Mahoney and Thelen, 2010) whereby there is rule change on the margins but the dominant traditional characteristics of the hierarchical mode of governance are not challenged. Whereas the situation in the new EU member states of Central and Eastern European countries in the 1990s was similar to Turkey's, both the involvement of the EU and pressure from local actors below had led national governments to willingly give up part of their exclusive control on regional governance in these countries. In Turkey's case the functioning and operations of the DAs are largely uncoupled from the EU process.

This article's focus has been on common patterns of regional governance challenges across regions. Nevertheless, a number of observations can be made with regard to regional variations. First, while all regions lack "cohesive regional developmental alliances" (Bruszt, 2008, 618), the one region that arguably comes closer to this notion is İzmir where a sense of regional purpose and direction and shared understandings among actors exist. In comparison to other regions, there are relatively more clear and precise views among local actors on a variety of issues concerning strategic priorities. One plausible reason is the pre-existing culture of associative relationships whereby a local cross-sectoral (business-led, but also including civic institutions and the public sector) alliance took the initiative to set up a DA for İzmir in the 1990s. Another possible reason is the relative lack of central government interference in İzmir economy (Ataöv and Eraydin, 2011). A third possible reason is that being a one-province region, İzmir largely escapes from problems caused by inter-provincial rivalries.

The political and policy implications of the DAs analyzed from a policy instruments approach in this article are manifold. At a minimum, as mechanisms for evidence-based policy making, such as regional databases, policy and program evaluations, and impact assessment, are not in place, both regional and national capacity for policy innovation through learning is severely limited. Moreover, the analysis in this article shows that the DAs in Turkey are largely failing to mobilize endogenous growth capacities through developmental collaborations between local actors. Above all, short-term inward looking concerns of the local political and business elites in the distribution of the DAs' financial resources serve to consolidate existing local power structures rather than transforming them. As such it is reasonable to claim, on the basis of empirical findings, that the political consequences of the functioning of DAs are making it even more difficult to transform these power relations through public policies in the future.

\section{APPENDIX 1. List of Interviewees}

In order to ensure full anonymity for the interviewees, the list does not disclose the identity of the regions.

1. Region A, General Secretariat

2. Region A, Development Council, NGO

3. Region A, Executive Board, private sector 
4. Region A, Executive Board, public sector

5. Region B, General Secretariat

6. Region B, Development Council, NGO

7. Region B, Development Council, NGO

8. Region B, Chamber of Industry

9. Region C, Provincial General Assembly

10. Region C, Executive Board, public sector

11. Region C, General Secretariat

12. Region C, General Secretariat

13. Region C, General Secretariat

14. Region $C, C$ Chamber of Commerce and Industry

15. Region C, Executive Board, private sector

16. Region $C$, Chamber of Commerce and Industry

17. Region C, Development Council, public sector

18. Region C, Development Council, private sector

19. Region D, Development Council, private sector

20. Region D, Executive Board, private sector

21. Region D, General Secretariat

22. Region E, General Secretariat

23. Region E, General Secretariat

24. Region E, General Secretariat

25. Region E, General Secretariat

26. Region E, Development Council, municipality

27. Region E, Development Council, municipality

28. Region E, Development Council, municipality

29. Region F, General Secretariat

30. Region F, General Secretariat

31. Region F, General Secretariat

32. Region F, Governorate,

33. Region F, Governorate

34. Region F, Governorate

35. Region F, Development Council, public sector

36. Region F, Chamber of Commerce and Industry

37. Region F, Chamber of Commerce and Industry

\section{BIBLIOGRAPHY}

ACEMOĞLU, D., JOHNSON, S.H. (2006) De Facto Political Power and Institutional Persistence, American Economic Review 96 (2) 325-30.

ATAÖV, A., ERAYDIN. A. (2011) Different Forms of Governance: Responses of Two Metropolitan Regions in Turkey to State ReStructuring, Urban Affairs Review 47(1) 84-128.

BACHE, I. (2010) Partnership as an EU Policy Instrument: A Political History, West European Politics 33(1) 58-74.

BACHE, I., FLINDERS, M., eds. (2005) Multi-level Governance, Oxford University Press, Oxford.

BARCA, F. (2009a) An Agenda for a Reformed Cohesion Policy: A Place-Based Approach to Meeting European Union Challenges and Expectations, Independent Report Prepared at the Request of the European Commissioner for Regional Policy, European Commission, Brussels; 1-218. 
BARCA, F. (2009b) Pursuing Equity through Place-based Development Policies. Rationale and the Equity-Efficiency Issue, presentation at the OECD/ TDPC Symposium on Regional Policy, Paris. (2 December 2009).

BELLINI, N., DANSON, M., HALKIER, H. (2012a) Regional Development Agencies: A Generational Story, Regional Development Agencies: The Next Generation?, eds. N. Bellini, M. Danson, H. Halkier, Routledge, London; 1-6.

BELLINI, N., DANSON, M., HALKIER, H. (2012b) RDA Futures?, Regional Development Agencies: The Next Generation?, eds. N. Bellini, M. Danson, H. Halkier, Routledge, London; 307-11.

BÖHME, K., WATERHOUT, B. (2008) Europeanization of Planning, European Spatial Research and Planning, ed. A. Faludi, Lincoln Institute of Land Policy, Cambridge; 225-48.

BRAMANTI, A., ROSSO, P. (2012) The Uneasy Future of Italian RDAs: The Good, The Bad and The Ugly, Regional Development Agencies: The Next Generation?, eds. N. Bellini, M. Danson, H. Halkier, Routledge, London; 264-83.

BRUSZT, L. (2008) Multi-Level Governance-The Eastern Versions: Emerging Patterns of Regional Developmental Governance in The New Member States, Regional and Federal Studies 18(5) 607-27.

COMMISSION OF THE EUROPEAN COMMUNITIES (CEC) (1988) Council Regulation EEC No 2052/88 of 24.03.88 in Official Journal of the European Communities, No L 185; 15.07.88. Commission of the European Communities: Brussels.

COOKE, P., MORGAN, K. (1993) The Network Paradigm: New Departures in Corporate and Regional Development, Environment and Planning $D(11), 543-64$.

CREVOISIER, O., JEANNERAT, H. (2009) Territorial Knowledge Dynamics: From The Proximity Paradigm to Multi-Location Milieus, European Planning Studies 17(8) 1223-41.

DAHLSTRÖM, M., OLSEN, L. S., HALKIER, H. (2012) Multi-Actor and Multi-Scalar Regional Development Policies in The Knowledge Economy, Regional Development Agencies: The Next Generation?, eds. N. Bellini, M. Danson, H. Halkier, Routledge, London; 7-23.

DANSON, M., LLOYD, G. (2012) Devolution, Institutions, and Organisations: Changing Models of Regional Development Agencies, Environment and Planning C-Government and Policy 30(1) 78-94.

DEVLET DENETLEME KURULU (DDK) (2014) Türkiye'nin Kalkınma Ajansları Uygulamasının Değerlendirilmesi (Evaluation of Turkey's Development Agencies), Research and Analysis Report, publication no. 2014/3, T.C. Cumhurbaşkanlığ1 Devlet Denetleme Kurulu, Ankara. [http://www.tccb.gov.tr/assets/dosya/20140130-2014-03.PDF] Access Date (30.06.2015).

DENZIN, N. K. (1989) The Research Act: A Theoretical Introduction to Sociological Methods, Prentice Hall, Englewood Cliffs, N. J.

DICLE DEVELOPMENT AGENCY (2013) TRC3, Mardin-Batman, ŞırnakSiirt, 2014-2023 Bölgesel Gelişme Planı (TRC3, Mardin-Batman, ŞırnakSiirt, 2014-2023 Regional Development Plan). [http://www.dika.org.tr/ 
photos/files/TRC3_2014-2023_Bölgesel_Gelişme_Planı.pdf] Access Date (12.12. 2015)

DRAFT LAW (2005) Kanun Tasarısı (Draft Law), Ankara, T.C. Başbakanlık. [http://www2.tbmm.gov.tr/d22/1/1-0950.pdf] Access Date (08.11.2015)

DUNLOP, C. A., MAGETTI, M., RADAELLI, C. M., RUSSEL, D. (2012) The Many Uses of Regulatory Impact Assessment: A Meta-Analysis of EU and UK Cases, Regulation and Governance 6(1) 23-45.

ERAYDIN, A., TAŞAN-KOK, T. (2014) State Response to Contemporary Urban Movements in Turkey: A Critical Overview of State Entrepreneurialism and Authoritarian Interventions, Antipode 46(1) $110-29$.

ERTUGAL, E. (forthcoming) Learning and Policy Transfer in Regional Development Policy in a Developing Country: Case Study of Turkey, Regional Studies.

FAGERBERG, J., SRHOLEC, M. (2008) National Innovation Systems, Capabilities and Economic Development, Research Policy 37, 1417-35.

FERRY, M. (2007) From Government to Governance: Polish Regional Development Agencies in a Changing Regional Context, East European Politics and Societies 21(3) 447-74.

GERTLER, M.S. (1997) The invention of regional culture, Geographies of Economies, eds. R. Lee, J. Willis, Arnold, London; 47-58.

HALKIER, H. (2006) Institutions, Discourse and Regional Development. The Scottish Development Agency and the Politics of Regional Policy, PIE Peter Lang, Brussels.

HALKIER, H. (2012a) Knowledge Dynamics and Policies for Regional Development: Towards a New Governance Paradigm, European Planning Studies 20(11) 1767-84.

HALKIER, H. (2012b) Regional Development Agencies, Regional Policy and Knowledge Dynamics, Regional Development Agencies: The Next Generation?, eds. N. Bellini, M. Danson, H. Halkier, Routledge, London; 24-51.

HALKIER, H., DANSON, M. (1997) Regional Development Agencies in Western Europe: A Survey of Key Characteristics and Trends, European Urban and Regional Studies 4(3) 243-56.

HOOD, C. (1986) The Tools of Government, Chatham House, Chatham.

HUGHES, J., SASSE, G., GORDON, C. (2004) Europeanization and Regionalization in the EU's Enlargement to Central and Eastern Europe: The Myth of Conditionality, Palgrave Macmillan, Basingstoke.

İSTANBUL DEVELOPMENT AGENCY (2014) 2014-2023 İstanbul Bölge Planı (2014-2023 İstanbul Regional Plan). [http://www.istka.org.tr/ content/pdf/2014 2023\%20istanbul\%20bolge\%20Plani_opt.pdf.] Access Date (05.12.2015).

IZMIR DEVELOPMENT AGENCY (2016). Activity Report 2015 (Faaliyet Raporu 2015). http://www.izka.org] Access Date (25.04.2016).

JOHANSSON, M., RYLANDER, D. (2012) Swedish Regions: Networking, Knowledge and Regional Change, Regional Development Agencies: The 
Next Generation?, eds. N. Bellini, M. Danson, H. Halkier, Routledge, London; 284-306.

JONES, M. (2003) The Rise of the Regional State in Economic Governance: 'Partnership for Prosperity' or New Scales of Power?, Environment and Planning A (33), 1185-211.

KASSIM, H., LE GALES, P. (2010) Exploring Governance in a Multi-Level Polity: A Policy Instruments Approach, West European Politics 33(1) $1-21$.

KAYASÜ, S., ELDENIZ, F. (2013) Institutional performance of İzmir Development Agency, METU Journal of the Faculty of Architecture 30(1) 57-78.

KALKINMA BAKANLIĞI (2012) Kalkınma Ajansları 2011 Yilı Faaliyet Raporu (Development Agencies Activity Report 2011), T.C. Kalkınma Bakanlığı, Ankara.

KALKINMA BAKANLIĞI (2013) Kalkınma Ajansları 2012 Yılı Faaliyet Raporu (Development Agencies Activity Report 2012), T.C. Kalkınma Bakanlığı, Ankara.

KALKINMA BAKANLIĞI (2014) Bölgesel Gelişme Ulusal Stratejisi 2014-2023 (National Strategy for Regional Development), T.C. Kalkınma Bakanlı̆̆ı, Ankara.

KEATING, M. (2008) Thirty Years of Territorial Politics, West European Politics 31(1-2) 60-81.

LAGENDIJK, A., KAYASU, S., YASAR, S. (2009) The Role of Regional Development Agencies in Turkey: From Implementing EU Directives to Supporting Regional Business Communities?, European Urban and Regional Studies 16(4) 383-96.

LARSEN, P. W. (2012) Analysing Regional Development through a Governance-Partnership Continuum, Regional Development Agencies: The Next Generation?, eds. N. Bellini, M. Danson, H. Halkier, Routledge, London; 122-38.

LASCOUMES, P., LE GALES, P. (2007) Introduction: Understanding Public Policy through Its Instruments-From the Nature of Instruments to the Sociology of Public Policy Instrumentation, Governance 20(1) 1-21.

MAHONEY, J., THELEN, K. (2010) A Theory of Gradual Institutional Change, Explaining Institutional Change: Ambiguity, Agency, and Power, eds. J. Mahoney, K. Thelen, Cambridge University Press, Cambridge; 1-37.

MAJONE, G. (1989) Evidence, Argument and Persuasion in the Policy Process, Yale University Press, New Haven.

MARKS, G. (1993) Structural Policy and Multilevel Governance in The EC, The State of the European Community: The Maastricht Debates and Beyond, eds. A. Cafruny, G. Rosenthal, Longman, Harlow; 391-410.

ORGANIZATION FOR ECONOMIC COOPERATION AND DEVELOPMENT (OECD) (2008) OECD Territorial Reviews: Istanbul, Turkey, OECD, Paris.

OFFICIAL JOURNAL (2006a) Kalkınma Ajanslarının Kuruluşu, Koordinasyonu ve Görevleri Hakkında Kanun (Law on the Establishment, Coordination and Tasks of Development Agencies), No. 26074, 8 February 2006. 
OFFICIAL JOURNAL (2006b) Kalkınma Ajansları Personel Yönetmeliği (Bylaw on Development Agencies Personnel), No. 26239, 25 July 2006.

OFFICIAL JOURNAL (2013) Decree of the Council of Ministers, Decree no 2013/4748, No. 28663, 31 May 2013.

PEARCE, G., AYRES, S. (2009) Governance in the English Regions: The Role of the Regional Development Agencies, Urban Studies 46(3) 537-57.

PIKE, A., TOMANEY, J., COOMBES, M., MCCARTHY, A. (2012) Governing Uneven Development: The Politics of Local and Regional Development in England, Regional Development Agencies: The Next Generation?, eds. N. Bellini, M. Danson, H. Halkier, Routledge, London; 102-21.

RADAELLI, C. M., MEUWESE, A. C. M. (2010) Hard Questions, Hard Solutions: Proceduralisation through Impact Assessment in The EU, West European Politics 33(1) 136-53.

RONCEVIC, B. (2012) Regional Development Agencies and Changing Social Fields, Regional Development Agencies: The Next Generation?, eds. N. Bellini, M. Danson, H. Halkier, Routledge, London; 87-101.

SALAMON, L., ed. (2002) The Tools of Government, A Guide to the New Governance, Oxford University Press, New York.

Sayıştay Başkanlığı (2014) Kalkınma Ajansları 2012 Yılı Genel Denetim Raporu (Development Agencies General Audit Report for the year 2012), Sayıştay Başkanlığı, Ankara.

SCHOUT, J. A., JORDAN, A. J. (2007) From Cohesion to Territorial Policy Integration (TPI): Exploring the Governance Challenges in the European Union, European Planning Studies 15(6) 835-51.

SHAW, P. W. R., LLOYD, M. G. (2000) Regional Development Agencies in England: New Strategic Regional Planning Issues?, Regional Studies 34(1) 75-9.

STREECK, W., THELEN, K. (2005) Introduction: Institutional Change in Advanced Political Economies, Beyond Continuity: Institutional Change in Advanced Political Economies, eds. W. Streeck, K. Thelen, Oxford University Press, Oxford; 1-39.

SYRETT, S., SILVA, C. N. (2001) Regional Development Agencies in Portugal: Recent Developments and Future Challenges, Regional Studies 35(2) 174-80.

TBMM (2012) Parliamentary Investigation Proposal, $24^{\text {th }}$ period, $2^{\text {nd }}$ legislative year, no. 10/784 (17/04/2012), Ankara.

TEWDWR-JONES, M., PHELPS, N.A. (2000) Levelling the Uneven Playing Field: Inward Investment, Interregional Rivalry and the Planning System, Regional Studies 34(5) 429-40.

TÜRKÜN, A. (2011) Urban Regeneration and Hegemonic Power Relationships, International Planning Studies 16(1) 61-72.

VISSER, E., ATZEMA, O. (2008) With or Without Clusters: Facilitating Innovation through a Differentiated and Combined Network Approach, European Planning Studies 16(9) 1169-88.

WEBB D., COLLIS, C. (2000) Regional Development Agencies and the 'New Regionalism' in England, Regional Studies 34(9) 857-64. 
WORKING GROUP (Working Group on Social Policy Openings coordinated by the Eastern Black Sea Development Agency) (2012) Kuruluşundan Bugüne Kalkınma Ajanslarında Sosyal Politikalar (Social Policies of Development Agencies since their inception). [http://www. trakyaka.org.tr/uploads/docs/11092012oz7LBO.pdf] Access Date (05.01.2016).

Alındı: 24.10 2016, Son Metin: 16.05.2017

Anahtar Sözcükler: Siyasa aracl; bölgesel kalkınma; yönetişim; kalkınma ajansları; Türkiye.

\section{TÜRKIYYE'DE BÖLGESEL YÖNETIŞIMIIN ZORLUKLARI: KALKINMA AJANSLARININ ROLÜ}

Bu makale Türkiye'de kurulan Bölge Kalkınma Ajanslarının işlevlerini siyasa araçları yaklaşımı ile inceleyerek bölgesel yönetişim üzerindeki istenilen ve istem dışı sonuçlarını tespit etmeyi amaçlamaktadır. Siyasa araçları yaklaşımı, araçların siyasa hedeflerini en etkili şekilde gerçekleştirmek üzere kurgulanmış sadece teknik ve tarafsız aygıtlardan ibaret olduklarını öne süren işlevselci görüşe karşı çıkmaktadır. Aksine, makale göstermektedir ki siyasa araçları olarak Kalkınma Ajansları son derece siyasidir ve işleyişlerinin önemli siyasi sonuçları vardır. Makale, resmi doküman ve raporların kapsamlı bir değerlendirmesi ile 2011 ve 2014 yılları arasında altı farklı bölgede yerel paydaşlarla yapılmış yarıyapılandırılmış mülakatlardan elde edilmiş orijinal verilerin analizine dayanmaktadır. Bulgular ışığında makale Kalkınma Ajanslarının, gerek ulus-altı aktörleri güçlendirebilecek odak noktaları olarak hareket etme kapasitelerinin, gerekse de kamu, özel sektör ve sivil toplum arasında bölge içi ağları teşvik etme kapasitelerinin zayıf olduğunu savunmaktadır. Bulgular, siyasa döngüsü içerisinde karar verme ve uygulama safhalarında yerel aktörler arasında ve yerel aktörlerle merkezi aktörler arasında işbirliği olmadığını, yerel aktörlerin Kalkınma Ajanslarını, yeni kalkınma imkânları üretecek ortaklıklar olarak değil de, kendi amaçlarını gerçekleştirmek üzere kullanabilecekleri aygitlar olarak gördüklerini göstermektedir. Bu bulguların işaret ettiği, Kalkınma Ajanslarının içsel büyüme kapasitelerini harekete geçirememelerinin bölgelerinde kalkınma motoru işlevi görmelerine engel olduğudur. Genel olarak Kalkınma Ajansları bölgesel kalkınmayı destekleme amaçlı çok düzlemli yönetişim ilişkilerini yürütmede büyük ölçüde başarısız kalmaktadırlar.

\section{CHALLENGES FOR REGIONAL GOVERNANCE IN TURKEY: THE ROLE OF DEVELOPMENT AGENCIES}

This article examines the functioning of Regional Development Agencies (DAs) in Turkey from a policy instruments approach with a view to uncovering their intended and unintended consequences for regional governance. The policy instruments approach challenges the functionalist view that instruments are merely technical and neutral devices for realizing policy aims in the most effective way. Instead, the article shows that as policy instruments, the DAs are highly political with important political consequences. The article is based on original data collected and generated from an extensive review of official documents and reports and semi-structured interviews with local stakeholders in six different regions conducted between 2011 and 2014. On the basis of the findings, 
the article argues that the DAs in Turkey lack the capacity to act as focal points for empowerment of sub-national actors and to foster intra-regional networks between public and private sectors and civil society. Findings show that there is lack of collaboration both between and among different groups of local and those of central actors within the decision-making and implementation stages of the policy cycle and that local actors perceive the DAs as devices for accomplishing their own objectives rather than as partnerships for producing new possibilities of development. These findings indicate that the DAs are far from mobilizing endogenous growth capacities, greatly hindering them from becoming engines of development in their regions. Overall, the DAs are largely failing to manage multiscalar relations of governance for the purpose of promoting regional development.

EBRU ERTUGAL; BA., MA., PhD.

Received her BA in international relations and MA in european studies from Marmara University in 1989 and 1995 respectively. Received her second MA in international political economy from the University of Warwick (1995-1996). Earned her PhD. degree in political science from KU Leuven. ertugal@baskent.edu.tr 